\title{
Candidate gene studies in pedigrees with maturity-onset diabetes of the young not linked with glucokinase
}

\author{
Y. Zhang ${ }^{1}$, M. Warren-Perry ${ }^{1}$, P.J. Saker ${ }^{1}$, A.T. Hattersley ${ }^{1}$, A. D. R. Mackie $^{2}$, J. D. Baird ${ }^{3}$, R.H. Greenwood ${ }^{4}$, \\ M. Stoffel ${ }^{5}$, G. I. Bell ${ }^{5}$, R. C. Turner ${ }^{1}$ \\ ${ }^{1}$ Diabetes Research Laboratories, Radcliffe Infirmary, Woodstock Road, Oxford, UK \\ ${ }^{2}$ Department of Diabetes and Endocrinology, Addenbrookes Hospital, Cambridge, UK \\ ${ }^{3}$ Metabolic Unit, University Department of Medicine, Western General Hospital, Edinburgh, UK \\ ${ }^{4}$ Norfolk and Norwich Hospital, Norwich, UK \\ ${ }^{5}$ Howard Hughes Medical Institute and Department of Medicine, The University of Chicago, Chicago, Illinois, USA
}

Summary Maturity-onset diabetes of the young (MODY) is a form of non-insulin-dependent diabetes mellitus characterised by an early age of onset and an autosomal dominant mode of inheritance. Only a proportion of cases are due to mutations in the glucokinase gene. We have studied five Caucasian MODY families, including the first MODY family to be described, with five candidate genes implicated in regulation of insulin secretion. The affected subjects showed more marked hyperglycaemia than that found in subjects with glucokinase mutations. We assessed polymorphic markers close to the genes for glucokinase, hexokinase II, adenosine deami- nase, pituitary adenylate cyclase-activating polypeptide receptor, and glucagon-like peptide- 1 receptor. Linkage analysis with diabetes gave cumulative log of the odds (LOD) scores of less than -3 , implying that mutations in these genes are unlikely to provide a major genetic contribution to this form of MODY. [Diabetologia (1995) 38: 1055-1060]

Key words Maturity-onset diabetes of the young, glucokinase, adenosine deaminase, pituitary adenylate cyclase-activation polypeptide receptor, hexokinase II, glucagon-like peptide-1 receptor, polymerase chain reaction, linkage analysis.
Non-insulin-dependent diabetes mellitus (NIDDM) is likely to have a genetic basis in view of the different incidences between ethnic groups, the familial nature of the disease and the high concordance in identical twins [1-3]. The use of linkage analysis to study candidate genes in families with classic, late-onset NIDDM is problematic because family studies do not indicate simple Mendelian inheritance $[4,5]$ and the late age of onset and early mortality make it diffi-

Received: 25 October 1994 and in revised form: 27 February 1995

Corresponding author: Dr. R.C. Turner, Diabetes Research Laboratories, Radcliffe Infirmary, Woodstock Road, Oxford OX2 6HE, UK

Abbreviations: MODY, Maturity-onset diabetes of the young; GCK, glucokinase; ADA, adenosine deaminase; PACAP-R, pituitary adenylate cyclase-activation polypeptide receptor; HK-2, hexokinase II; GLP-1 R, glucagon-like peptide-1 receptor; PCR, polymerase chain reaction; STRP, simple tandem repeat polymorphism; NIDDM, non-insulin-dependent diabetes mellitus. cult to obtain large multigeneration families suitable for genetic studies [6]. NIDDM is likely to be heterogeneous, with mutations in several different genes being liable to induce hyperglycaemia $[7,8]$.

A subgroup of NIDDM, maturity-onset diabetes of the young (MODY) provides a specific phenotype, with presentation often before age 25 years, that is inherited as an autosomal dominant trait $[9$, 10]. Mutations in the glucokinase (GCK) gene were first found in pedigrees with MODY $[11,12]$ and may account for half of the MODY pedigrees [13]. The nature of the genetic lesion in the other families is unknown. The first gene implicated in the development of MODY was identified by exclusion mapping in the large RW pedigree, with the observation of linkage with markers close to the adenosine deaminase (ADA) gene [14]. The affected members have recently been shown to have beta-cell dysfunction [15]. Identification of other pedigrees linked with adenosine deaminase (ADA) would be helpful in the further localisation of the gene in chromosome $20 \mathrm{q}$. 
Whereas NIDDM may result from defects in insulin action as well as insulin secretion $[16,17]$ the available data suggest that MODY is primarily due to beta-cell deficiency $[12,18]$. Genes that could regulate insulin secretion are candidates for mutations that could lead to MODY, include glucokinase and hexokinase II (HK-2), since the latter is also expressed in beta-cells $[19,20]$. Beta-cell sensitivity to glucose is regulated by several hormones, including acetylcholine, glucagon, and glucagon-like peptide-1 (GLP-1), and their receptors are potential candidate genes [21]. The recently described pituitary adenylate cyclase activation polypeptide (PACAP), which is a member of the secretin/glucagon/vasoactive intestinal peptide family of peptides, is a particularly potent stimulator of insulin secretion from pancreatic islets, at $10^{-10}$ to $10^{-9}$ mol concentration [22].

We report the results of linkage analyses of these candidate genes for regulation of beta-cell secretion with MODY in five Caucasian families, including the first MODY pedigree described by Tattersall [9]. We report the phenotype in these families, which show more marked hyperglycaemia and more often require pharmaceutical therapy than in the milder disease associated with glucokinase mutations [23].

\section{Subjects and methods}

Subjects. Five Caucasian MODY families are shown in Figure 1. They live in London, Oxford, Leicester, Norwich and Edinburgh and were referred by diabetologists. Each family had three patients with NIDDM diagnosed before the age of 25 years and included sufficient members for linkage studies.

Phenotype. Table 1 shows the age of onset, initial therapy and current status of patients in the pedigrees studied. Pedigree 1 is the original MODY pedigree described as "M" [9].

Genetic studies. DNA was extracted from peripheral blood using either the standard phenol/chloroform method [24] or Nucleon II DNA extraction Kit (Scotlab, UK). Subjects were genotyped at simple tandem repeat DNA polymorphisms (STRPs) near ADA, GCK, HK2, PACAP-R, and GLP-1R (Table 2) using the polymerase chain reaction (PCR). The ADA STRP, D20S119, is different from that used by Bell et al. [14]. The data for GLP-1R have been published previously [25]. The PCR products were separated by electrophoresis on a non-denaturing polyacrylamide gel and bands were detected by ethidium bromide staining.

Linkage analysis. Each family was considered separately for linkage analysis performed with the software LINKAGE program (version 5.1) assuming dominant inheritance [26]. As candidate genes were being examined, LOD (logarithm of the odds for linkage vs non-linkage) scores were primarily calculated with the recombination fraction theta $(\theta)$ equal to zero. Values at other recombination fractions were determined to provide an exclusion map around those markers and are available from the authors. Liability classes were based on age-related penetrance, calculated from the incidence of diabetes in first-degree relatives of MODY patients [27] and prevalence studies of diabetes in the general population. Five liability classes for MODY were defined on the basis of age (class $1,>50$ years; class $2,41-50$ years; class $3,31-40$ years; class 4 , $21-30$ years; class $5,<20$ years). The penetrance factors for heterozygous and homozygous genotypes used for MODY were $0.99,0.95,0.90,0.80,0.60$ for heterozygosity and 1 for homozygosity at all ages. Since the clinical presentation in these families was similar to that for classic NIDDM, phenocopy rates for each liability class were those of the prevalence of NIDDM in the UK $0.03,0.005,0.001,0.001$, and 0.0001 respectively. For comparison, the characteristics of patients in two large MODY pedigrees $\mathrm{BX}$ and $\mathrm{AX}$, due to a missense mutation of the glucokinase gene, are also shown [23].

\section{Results}

Table 1 shows that the patients were non-obese and presented at median age 17 years, when $50 \%$ were initially treated by diet and $50 \%$ by oral hypoglycaemic agents or insulin. When recently assessed, at median age 29 years, the subjects were not obese, median body mass index (BMI) $23 \mathrm{~kg} \cdot \mathrm{m}^{-2}$. Onethird were treated by diet at median age 26 years and had median fasting blood glucose levels $7 \mathrm{mmol} /$ 1. One-third were treated by oral hypoglycaemic agents at median age 43 years and had median fasting blood glucose levels $10 \mathrm{mmol} / \mathrm{l}$. One third were treated by insulin at median age 26 years and had median fasting blood glucose level $7 \mathrm{mmol} / \mathrm{l}$.

Figure 1 shows family trees with the genotypes for the PACAP-R polymorphism [28] in the MODY pedigrees. Table 3 shows the LOD scores at a recombination fraction $(\theta)$ of 0.00 for each family for the markers studied. The cumulative LOD scores for each marker were less than -2.0 . The maximum positive LOD scores that could be achieved in these five pedigrees are 4.0, 2.3, 1.4, 3.3 and 8.4, respectively, with a cumulative maximum of 19.4 .

\section{Discussion}

In only one [12] of the six large UK MODY pedigrees we investigated has a glucokinase mutation been identified. None of the five pedigrees reported in this study were linked to the glucokinase gene, the cumulative LOD scores for the two markers being -11.5 and -17.6 , respectively. This contrasts with the report from France that glucokinase mutations account for over $50 \%$ of MODY pedigrees [13]. This difference

Fig. 1. The MODY pedigrees [1-5] showing the inheritance of PACAP-R alleles. Roman numerals on the left of the pedigrees indicate generation number, and the numbers above the symbols indicate the subject's number within each pedigree. The PACAP-R DNA polymorphism alleles are noted under the symbols. $\square$, males; $\bigcirc$, females; $\square$, diabetes; diagonal shading, glucose intolerance; open symbol, normoglycaemia; central dot, not tested; slash, deceased 
(1)

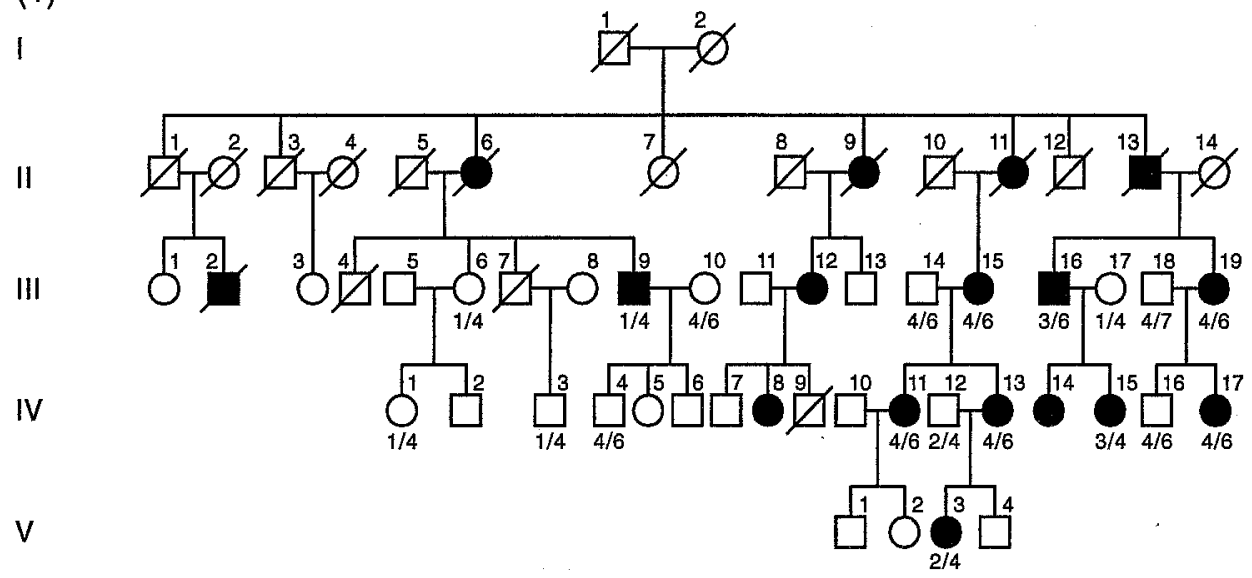

(2)

I

II

III

IV
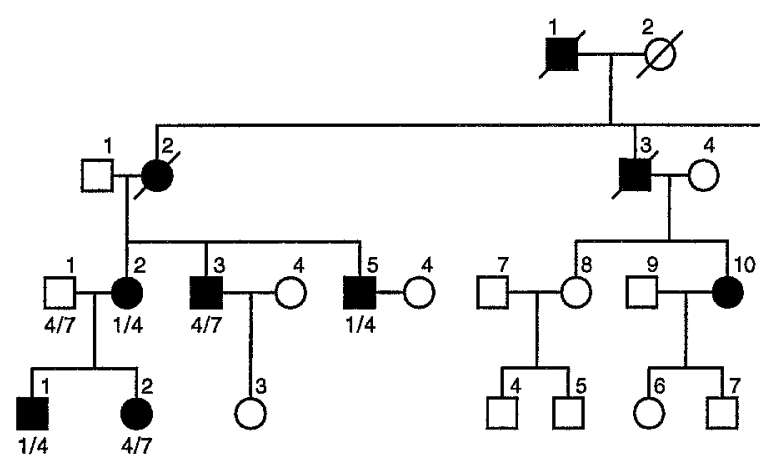

(4)

I

II

III

IV

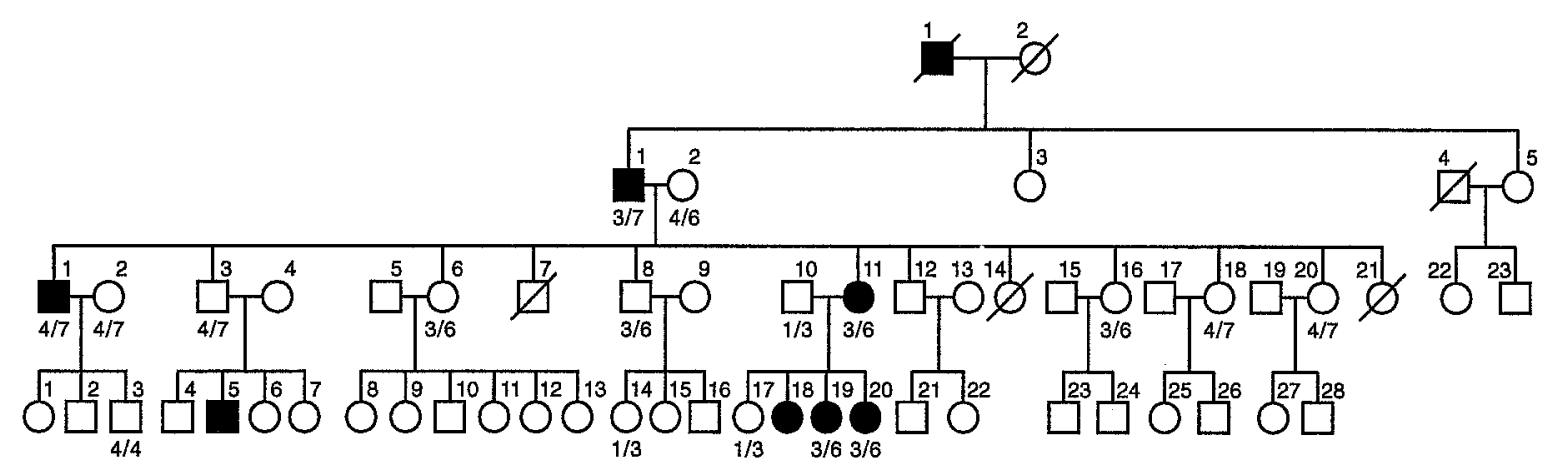

(5)

I

II

III

iv

v

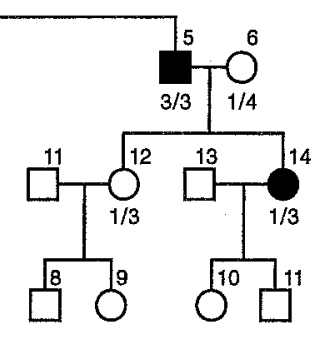

II

(3)

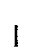

-1. $\mathrm{T}^{2}$

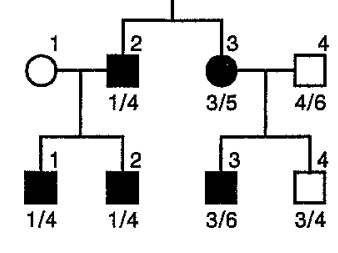

4)

西

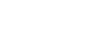

$\square_{4}^{2} \square^{3} \square^{5} O^{6} \frac{17}{18} \square^{9}$

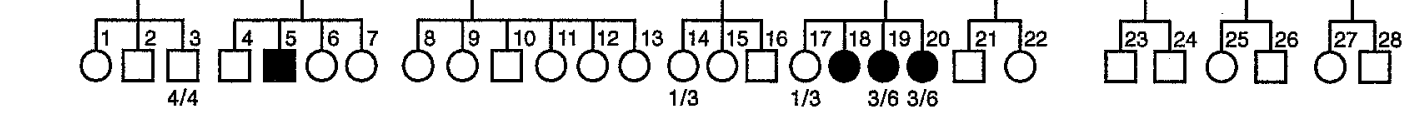

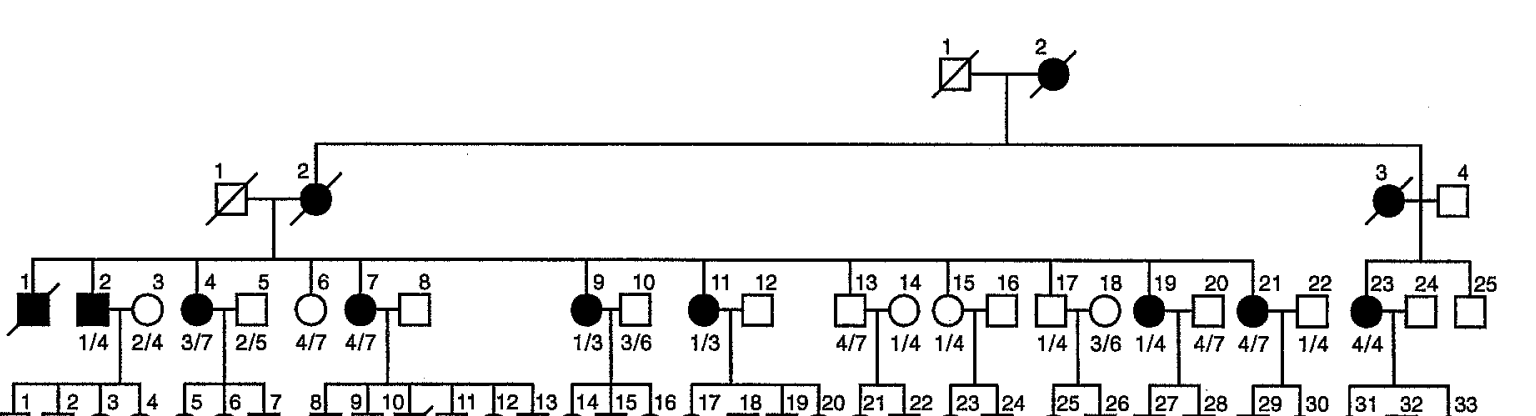

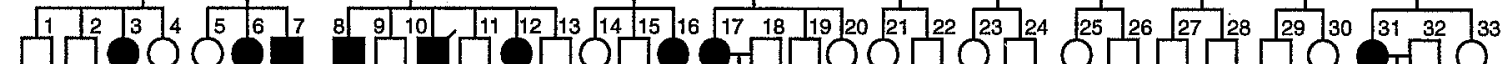 (a)


Table 1. Clinical characteristics of MODY patients in the five families and in subjects in pedigrees BX with glucokinase missense mutation

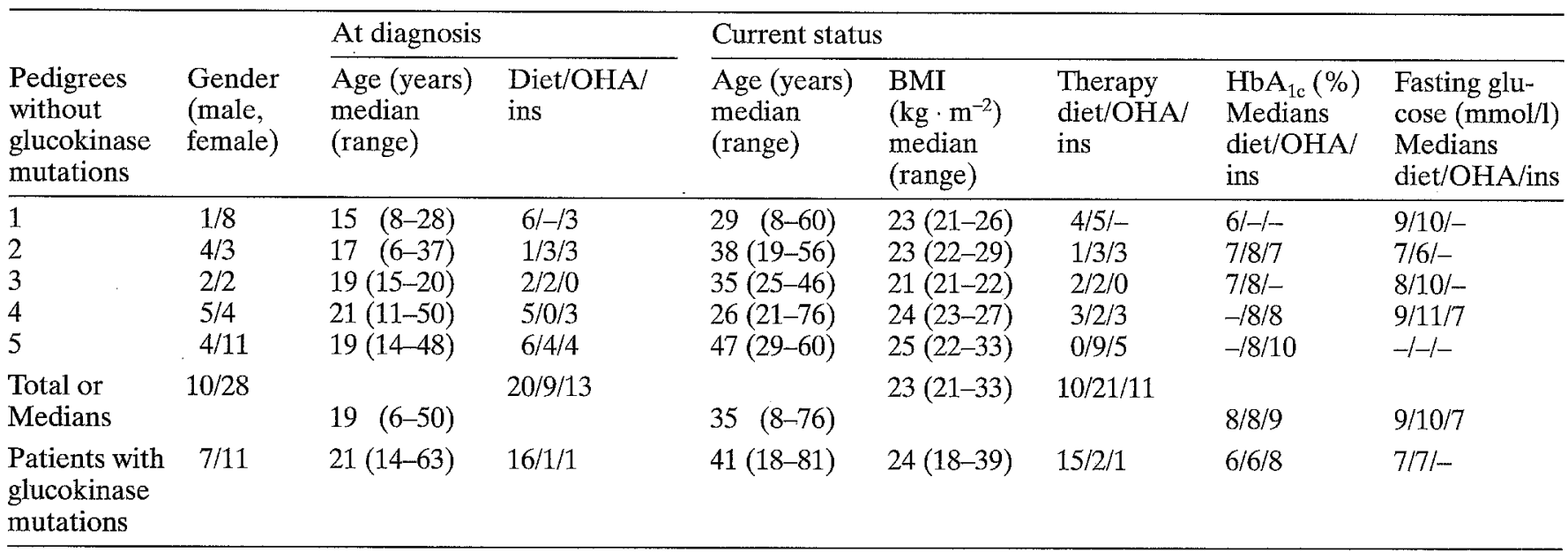

OHA, Oral hypoglycaemic agents; ins, insulin; $\mathrm{HbA}_{1 \mathrm{c}}$, haemoglobin $\mathrm{A}_{1 \mathrm{c}}$

Table 2. List of STRPs used as candidate gene markers

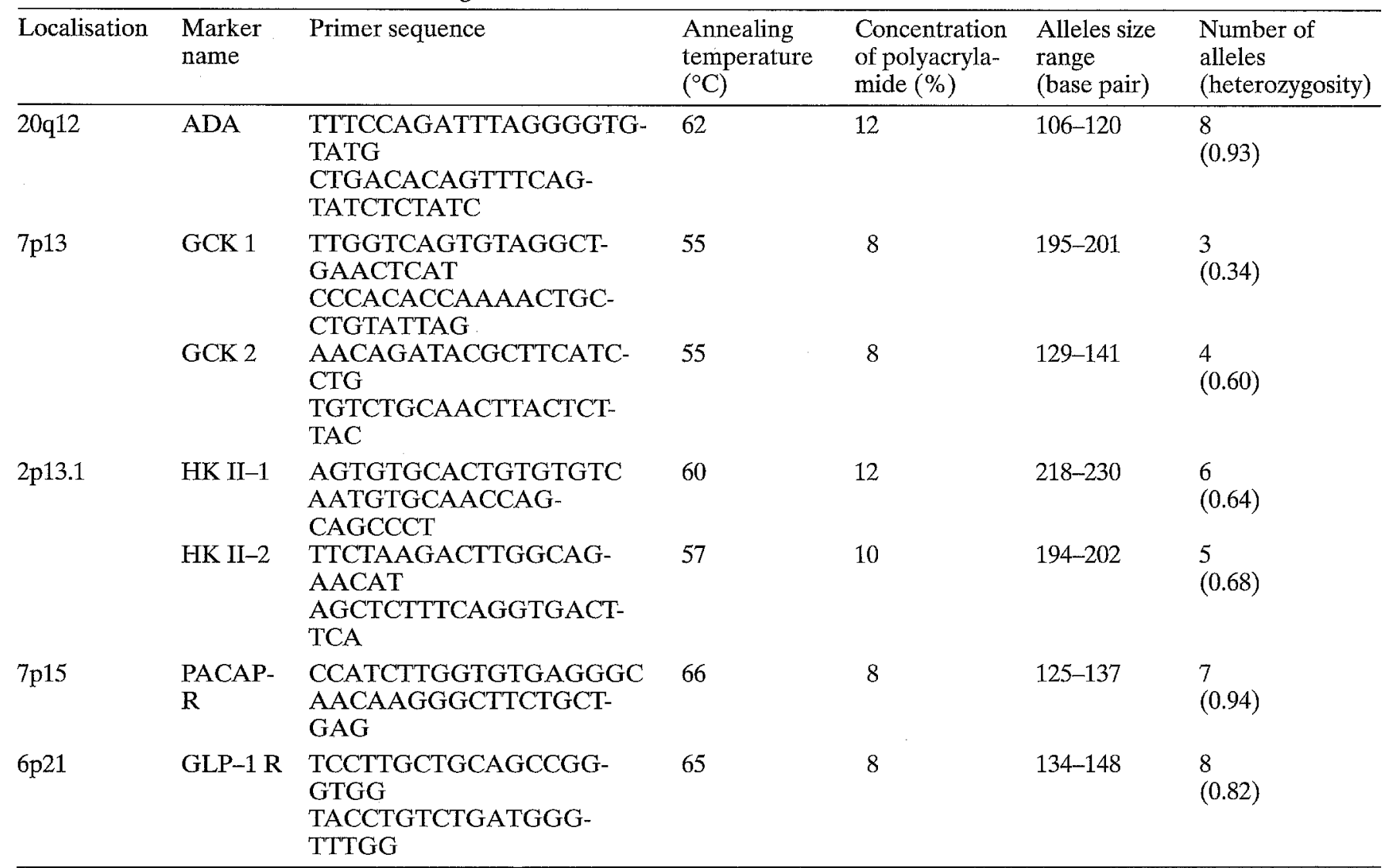

may result from ascertainment bias. We have primarily sought large pedigrees suitable for linkage analysis. The pedigrees were referred by diabetologists caring for adult diabetic patients, and were noticed because several members of the pedigrees had presented with symptomatic NIDDM before age 25 years. The French MODY pedigrees were often referred by paediatricians when mild diabetes was detected in the second decade and affected relatives were identified by screening asymptomatic relatives. This resulted in collection of a mild phenotype. Patients with glucokinase mutations frequently have impaired glucose tolerance rather than diabetes; most family members are asymptomatic and the sub-clinical diabetes rarely leads to complications $[12,23]$. On the other hand, our more hyperglycaemic pedigrees with 
Table 3. Pedigree LOD scores at $\theta=0.00$ for the five candidate genes

\begin{tabular}{|c|c|c|c|c|c|c|c|}
\hline \multirow[t]{2}{*}{ Families order } & \multirow[t]{2}{*}{$\mathrm{ADA}$} & \multicolumn{2}{|l|}{ GCK } & \multicolumn{2}{|l|}{ HK II } & \multirow[t]{2}{*}{ PACAP-R } & \multirow[t]{2}{*}{ GLP-1 R } \\
\hline & & 1 & 2 & 1 & 2 & & \\
\hline 1 & -2.90 & -4.63 & -4.97 & -0.76 & -5.23 & -5.03 & -2.59 \\
\hline 2 & -7.99 & -3.47 & -0.05 & 0.23 & -6.98 & -4.76 & -3.89 \\
\hline 3 & -1.75 & -2.35 & -2.44 & -2.99 & 0.00 & -2.90 & 0.00 \\
\hline 4 & -8.50 & -0.63 & -1.74 & 0.35 & -6.51 & -5.00 & -1.02 \\
\hline 5 & -6.18 & -0.47 & -8.46 & -3.39 & -9.09 & -11.29 & 0.00 \\
\hline $\begin{array}{l}\text { Cumulative LOD } \\
\text { scores }\end{array}$ & -27.31 & -11.54 & -17.55 & -6.56 & -27.81 & -28.98 & -8.50 \\
\hline
\end{tabular}

diabetes as defined by the World Health Organisation often required oral hypoglycaemic or insulin therapy and developed diabetic retinopathy and other diabetic complications.

The largest reported MODY pedigree is the RW pedigree in which linkage has been identified with markers close to the ADA chromosome 20. They also often require oral hypoglycaemic or insulin therapy and have impaired beta-cell function [15]. The localisation of the gene linked with diabetes in the region of ADA would be greatly aided by additional pedigrees, similar to the RW pedigree, but none of the large pedigrees we have studied are linked with markers close to ADA. It seems that the RW type of diabetes is likely to account for a minority of MODY.

These large pedigrees were not linked to either the glucokinase or hexokinase II genes. Whilst hexokinase II is predominately expressed in muscle and adipocytes, it is also expressed in beta-cells $[19,20]$. The remarkable increase of beta-cell and alpha-cell responsiveness to glucose by pharmacological infusions of GLP-1 in NIDDM [29] show the potential for defects in the response to the hormones that regulate beta-cell function via a cyclic-AMP-dependent process. PACAP is the most potent hormone of this class [22], but we found that neither the PACAP receptor nor the GLP-1 receptor [25] were linked to diabetes in the MODY families studied.

Linkage analysis in pedigrees is a powerful tool for examining the role of candidate genes in the aetiology of inherited diseases with a defined mode of transmission [30]. Families with MODY are particularly amenable as they have a clearly discernible autosomal dominant inheritance and the early age of onset allows ascertainment of affected members over three generations $[6,31,32]$. When doing linkage analysis, the parameters for age-related liability classes were chosen to take into account the prevalence of NIDDM in the general population and the apparent age-dependent penetrance in MODY pedigrees. The search for genes can be done by two complementary methods; by the candidate gene approach, as was successful with glucokinase, or with exclusion mapping, as in insulin-dependent diabetes mellitus [34].

We found no evidence of linkage with MODY for the five candidate genes that we studied in these fam- ilies. The results were not dependent on the models chosen and were, for instance, not affected by doubling the phenocopy rate or by increasing or decreasing by $50 \%$ the penetrance of the putative MODY gene. Diabetes in these pedigrees had some similarities to that in patients with classic, non-obese NIDDM, including similar beta-cell deficiency [12, $23,34]$. Identification of the genes relevant to betacell dysfunction and their exclusion in this form of MODY may be relevant to NIDDM as well as to MODY, but the candidate genes tested so far are not implicated in MODY [35].

Acknowledgements. We are grateful to Drs. W. O.C. Cookson, S. O'Rahilly, J. Cook, R. Page, and J.Levy for their assistance and advice. This study was supported by grants from the Wellcome Trust, the Alan and Babette Sainsbury Trust and Howard Hughes Medical Institute Foundation. A. T. Hattersley was an MRC Training Fellow. We thank Ms. I. Samuel and Ms. C. Wood for their assistance with the manuscript.

\section{References}

1. Pyke DA (1979) Diabetes: the genetic connection. Diabetologia 17: 333-343

2. Barnett AH, Eff C, Leslie RDG, Pyke DA (1981) Diabetes in identical twins. Diabetologia 20: 87-93

3. Newman B, Selby JV, King MC, Slemenda C, Fabsitz R, Friedman GD (1987) Concordance for type 2 (non-insulin-dependent) diabetes mellitus in male twins. Diabetologia 30: 763-768

4. Cook JTE, Hattersley AT, Levy JC et al. (1993) Distribution of type II diabetes in nuclear families. Diabetes 42 : $106-112$

5. Cook JTE, Shields DC, Page RCL et al. (1994) Segregation analysis of type 2 diabetes in Caucasian families. Diabetologia 37: 1231-1240

6. O'Rahilly S, Wainscoat JS, Turner RC (1988) Type 2 (noninsulin dependent) diabetes mellitus. New genetics for old nightmares. Diabetologia 31: 407-415

7. Stoffel M, Patel P, Lo Y-MD et al. (1992) Missense glucokinase mutation in maturity-onset diabetes of the young (MODY) and mutation screening in late-onset diabetes. Nature Genetics 2: 153-156

8. van den Ouweland JMW, Lemkes HHPJ, Ruitenbeck W et al. (1992) Mutation in mitochondrial tRNA teu(UUR) $^{\text {Led }}$ gene in a large pedigree with maternally transmitted type II diabetes mellitus and deafness. Nature Genetics 1: 368371 
9. Tattersall RB (1974) Mild familial diabetes with dominant inheritance. Q J Med 43: 339-357

10. Fajans SS (1989) Maturity-onset diabetes of the young (MODY). Diabetes Metab Rev 5: 579-606

11. Froguel P, Vaxillaire M, Sun F et al. (1992) Close linkage of glucokinase locus on chromosome $7 \mathrm{p}$ to early-onset noninsulin-dependent diabetes mellitus. Nature 356: 162-164

12. Hattersley AT, Turner RC, Permutt MA et al. (1992) Linkage of type 2 diabetes to the glucokinase gene. Lancet 339 : $1307-1310$

13. Froguel $P$, Zouali $H$, Vionnet N, Velho $G$, Vaxillaire $M$, Sun F (1993) Familial hyperglycemia due to mutations in glucokinase-definition of a subtype of diabetes mellitus. N Engl J Med 328: 697-702

14. Bell GI, Xiang KS, Newman MV et al. (1991) Gene for non-insulin-dependent diabetes mellitus (maturity-onset diabetes of the young subtype) is linked to DNA polymorphism on human chromosome 20q. Proc Natl Acad Sci USA 88: 1484-1488

15. Herman WH, Fajans SS, Ortiz FJ et al. (1994) Abnormal insulin secretion, not insulin resistance is the genetic or primary defect of MODY in the RW pedigree. Diabetes 43: 40-46

16. De Fronzo RA (1988) The triumvirate $\beta$-cell, muscle, liver: a collusion responsible for NIDDM. Diabetes 37: 730-735

17. Eriksson J, Franssila-Kallunki A, Ekstrand A et al. (1989) Early metabolic defects in persons at increased risk for non-insulin-dependent diabetes mellitus. New Eng J Med 321: $337-343$

18. Fajans SS (1989) Maturity-onset diabetes of the young (MODY). Diabetes Metab Rev 5: 579-606

19. Chan CB (1993) Glucokinase activity in isolated islets from obese fa/fa Zucker rats. Biochem J 295: 673-677

20. Chen C, Bumbalo L, Leahy JL (1994) Increased catalytic activity of glucokinase in isolated islets from hyperinsulinemic rat. Diabetes 43: 684-689

21. Stoffel M, Espinosa R, Lebeau MM, Bell GI (1993) Human glucagon-like peptide receptor gene: localization to chromosome band $6 \mathrm{p} 21$ by fluorescence in situ hybridization and linkage of a highly polymorphic simple tandem repeat DNA polymorphism to other markers on chromosome 6 . Diabetes 42: 1215-1218

22. Yada T, Sakurada M, Ihida K et al. (1994) Pituitary adenylate cyclase activating polypeptide is an extraordinarily potent intra-pancreatic regulator of insulin secretion from islet-cell. J Bio Chem 269: 1290-1293

23. Page RCL, Hattersley AT, Levy JC et al. (1994) Clinical characteristics of type 2 diabetes associated with a missense mutation in glucokinase. Diabet Med 12: 209-217
24. Maniatis T, Fritsch EF, Sambrook J (1982) Molecular cloning: a laboratory manual. Cold Spring Harbor Laboratory, Cold Spring Harbor, New York

25. Zhang Y, Cook JTE, Hattersley AT et al. (1994) Non-linkage of the glucagon-like peptide 1 receptor gene with maturity-onset diabetes of the young. Diabetologia 37: 721724

26. Lathrop GM, Laloud JM (1984) Easy calculation of LOD score and genetic risks on small computers. Am J Hum Genet 36: 460-465

27. O'Rahilly S, Trembath RC, Patel P, Galton DI, Turner RC, Wainscoat JS (1988) Linkage analysis of the human insulin receptor gene in type 2 diabetic families and a family with maturity-onset diabetes of the young. Diabetologia 31 : 792-797

28. Stoffel M, Espinosa III R, Trabb JB, Le Beau MM, Bell GI (1994). Human type 1 pituitary adenylate cyclase activating polypeptide receptor (ADCYAP1R): localization to chromosome $7 \mathrm{p} 14$ and integration into the cytogenic, physical and genetic map of chromosome 7. Genomics 23: 697-699

29. Nauck MA, Kleine N, Ørskov C, Holst JJ, Willms B, Creutzfeldt W (1993) Normalisation of fasting hyperglycaemia by exogenous glucagon-like peptide 1 (7-36 amide) in type 2 (non-insulin-dependent) diabetic patients. Diabetologia 36: 741-744

30. Ott J (1985) Analysis of human genetic linkage. 1st edn. John Hopkins University Press, Baltimore

31. Tattersall RB, Fajans S (1975) A difference between the inheritance of classical juvenile-onset and maturity-onset type diabetes of young people. Diabetes 24: 44-53

32. Kobberling J, Tillil H (1982) Empirical risk figures for the first degree relatives of non-insulin-dependent diabetes. In: Kobberling J, Tatersall $\mathbf{R}$ (eds) The genetics of diabetes mellitus. Academic Press, London, pp 201-209

33. Davies JL, Kawaguchi Y, Bennett ST et al. (1994) A genome-wide search for human type 1 diabetes susceptibility genes. Nature 371: 130-136

34. Multi-centre study: UK Prospective Diabetes Study V (1988) Characteristics of newly presenting type 2 diabetic patients: estimated insulin sensitivity and islet $\beta$-cell function. Diabet Med 5: 444-448

35. Vaxillaire M, Vionnet N, Vigouroux C et al. (1993) Search for a third susceptibility gene for maturity-onset diabetes of the young: studies with eleven candidate genes. Diabetes 43: 389-395 